\title{
Goals in Canadian Universities
}

\author{
ABRAM G. KONRAD* and JOANNE McNEAL**
}

\begin{abstract}
An examination of university goals provides an understanding of institutional purposes and priorities. The study reported here was designed to ascertain the goals of Canadian universities as perceived by presidents and board chairmen; to compare their perceptions of existing and preferred goals; and to compare perceptions by respondent position, and by region, age and size of university. Although some differences attributed to region and size were observed, perceptions of university goals were remarkably uniform. Generally, process goals were perceived more highly than the traditional outcome goals of teaching, research and service.
\end{abstract}

\section{RÉSUMÉ}

Un examen de la mission de l'Université est essentiel pour comprendre les priorités et objectifs institutionnels. Cette ètude fut effectuée pour avoir une idée précise de la mission des universités canadiennes telle que perçue par les présidents/ présidentes d'universités et les directeurs/directrices de conseils d'administration. Egalement, l'étude visait à comparer les perceptions existantes aux perceptions souhaitées selon le poste du répondant, de la région, de l'âge et de la taille de l'institution. A l'exception de quelques différences observées aux niveaux de la région et de la taille, les perceptions étaient très uniformes. De façon générale, les buts de type opérationnel étaient plus valorisés que ceux reliés à l'enseignement, la recherche et le service à la communauté.

In organizations, according to Parsons et al. (1961), goals and goal attainment has priority over all problems. Whether explicitly stated or not, goals provide the basic orientation of an organization. To define the goals of an organization is to clarify the very nature of its essence.

* University of Alberta

** Athabasca University 
Goals have functional value in an organization. According to Clifton Conrad (1974), goals may serve as standards by which to judge its success; constitute a source of legitimacy; define needs and priorities; define production units or outputs; define its clientele; and define the nature of the relationship between the organization and society. Rising demands for organizational accountability places greater expectations for goal clarity upon an organization.

As complex organizations, universities have been defined as "organized anar. chies" (Cohen and March, 1974) which are characterized by ill-defined goals, unclear technology, and fluid participation. The very complexity of universities makes it incumbent upon them to seek goal clarification.

The most comprehensive attempt to measure university goals was an extensive survey by Gross and Grambsch (1968) of administrators and faculty at sixtyeight major universities. Their study conceptualized forty-seven output and support goals in five categories and asked respondents to identify their perceived and preferred goals. A replication of their study in 1971 revealed only little change following the decade of the turbulent sixties. Gross and Grambsch (1974:3) concluded:

Universities remained in 1971 what they had been in 1964; institutions oriented toward research and scholarly production, set up to provide comfortable homes for professors and administrators, and according students and their needs a distinctly secondary position.

Beginning in 1969, a research group at Educational Testing Service, New Jersey, began the development of the Institutional Goals Inventory (IGI) designed to assess the perceived importance of goal statements according to present (Is) and preferred (Should Be) importance (Peterson, 1970). The IGI consists of eighty goal statements in twenty goal areas, thirteen of which are outcome goals - the substantive objectives of institutions; and seven are process goals - ways and means of functioning. In addition, the IGI contains ten miscellaneous goal statements and also provides for the option of ten local goal statements.

Since its publication in 1972, the IGI has been used in hundreds of colleges and universities in the United States and elsewhere. It has been translated into French, Spanish and even Saudi Arabian and Thai. Its popularity rests upon its ease of administration and interpretation of results. An excellent manual provides technical information and also serves as a helpful guide for its use (Peterson and Uhl, 1977). The most comprehensive use of the IGI was made by the California Joint Committee on the Master Plan for Higher Education (Peterson, 1973). Although the results are too massive to summarize here, the findings identified the congruence and divergence of perceptions held by samples of administrators, faculty, students, members of governing boards, and community citizens for the goals of California colleges and universities.

Several Canadian universities have used the IGI to identify goal priorities for institutional development. At the University of Ottawa (Piccinin and Joly, 1978), the IGI was used effectively to illuminate convergence and discrepancy of goals 
as perceived by administrators, faculty and students. The University of Manitoba (1977) surveyed six constituent groups - administrators, faculty, support staff, students, legislators, and community representatives - to help in clarifying goals for developmental plans at the institution. Several other Canadian universities have also used the IGI for planning purposes.

\section{METHODOLOGY}

The profile of Canadian university goals presented in this paper grew out of a project on university goals initiated in 1981 at the University of Alberta (McNeal, Konrad and Hodysh, 1981) and culminating in a graduate thesis (McNeal, 1982). The study was designed to ascertain the goals of Canadian universities as perceived by presidents and board chairmen; to compare their perceptions of existing and preferred goals: and to compare perceptions by respondent's position, and by region, age and size of university.

The Canadian edition of the Institutional Goals Inventory (IGI) was used in the survey. A French version was used for the francophone institutions in Quebec and New Brunswick.

Data collection and analysis occurred in the 1981-82 academic year. Questionnaires were mailed to all presidents of public degree-granting universities in Canada, and usable returns were received from thirty-eight (76 percent) of the fifty presidents and sixteen (33 percent) of the forty-eight board chairmen in Canadian universities. Returns were fairly evenly distributed across geographical regions, although Ontario had the lowest total response rate of only forty-six percent.

Although the validity of the board chairmen's responses was questionable due to their low returns, they were used as a comparison with the presidents' responses. On all other analyses, the data were combined from both groups in examining differences between existing and preferred goal perceptions by region, age and size of the university.

\section{THE FINDINGS}

The primary purpose of this paper is to provide an overview of Canadian university goals as perceived by presidents and board chairmen. The findings of this study can be generalized only to the extent that presidents and board chairmen reflect accurately the existing and preferred goals of Canadian universities.

\section{Goal Consensus}

This section portrays the ratings of both existing and preferred goals as perceived by the total sample. Mean scores show the average rating of perceived importance for each goal area - the higher the mean, the greater its perceived importance. The standard deviation (SD) shows the amount of agreement among respondents - the lower the standard deviation, the higher the consensus within the respondent group. 
Table 1

Perceptions of Major Goal Areas Ranked by Is and should Be Means

\begin{tabular}{|c|c|c|c|c|c|c|c|}
\hline \multicolumn{3}{|c|}{ Is } & \multicolumn{5}{|c|}{ Should be } \\
\hline Rank & Goal & Mean & SD & Rank & Goal & Mean & $S D$ \\
\hline 1. & Commonity $(P) \star$ & 3.71 & .61 & 1. & Oammunity $(P)$ & 4.29 & .55 \\
\hline 2. & $\begin{array}{l}\text { Democratic } \\
\text { Governance (P) }\end{array}$ & 3.53 & .58 & 2. & $\begin{array}{l}\text { Intellectual } \\
\text { Orientation (0) }\end{array}$ & 4.28 & .50 \\
\hline 3. & Freedom (P) & 3.51 & .94 & 3. & $\begin{array}{l}\text { Academic } \\
\text { Development (O) }\end{array}$ & 3.98 & .50 \\
\hline 4. & $\begin{array}{l}\text { Academic } \\
\text { Develogment (O) }\end{array}$ & 3.49 & .54 & 4. & $\begin{array}{l}\text { Accountability } \\
\text { Efficiency (P) }\end{array}$ & 3.87 & .63 \\
\hline 5. & $\begin{array}{l}\text { Intellectual } \\
\text { Orientation (O) }\end{array}$ & 3.42 & .68 & 5. & $\begin{array}{l}\text { Intel lectual } \\
\text { Environment (P) }\end{array}$ & 3.86 & .64 \\
\hline 6. & $\begin{array}{l}\text { Accountability/ } \\
\text { Efficiency (P) }\end{array}$ & 3.27 & .70 & 6. & $\begin{array}{l}\text { Derocratic } \\
\text { Governance (P) }\end{array}$ & 3.72 & .60 \\
\hline 7.5 & Research $(0)$ & 3.23 & .90 & 7. & $\begin{array}{l}\text { Individual Personal } \\
\text { Development }(0)\end{array}$ & 3.66 & .70 \\
\hline 7.5 & $\begin{array}{l}\text { Intellectual } \\
\text { Environment (P) }\end{array}$ & 3.23 & .68 & 8. & Freedom $(P)$ & 3.63 & .93 \\
\hline 9. & $\begin{array}{l}\text { Individual Personal } \\
\text { Development }(0)\end{array}$ & 2.97 & .74 & 9. & Research (0) & 3.61 & .78 \\
\hline 10. & $\begin{array}{l}\text { Meeting Local } \\
\text { Needs }(0)\end{array}$ & 2.95 & .58 & 10. & Innovation (P) & 3.41 & .62 \\
\hline 11. & Innovation (P) & 2.88 & .60 & 11. & $\begin{array}{l}\text { Meeting Local } \\
\text { Needs (O) }\end{array}$ & 3.36 & .52 \\
\hline 12. & Advanced Training $(0)$ & 2.85 & 1.06 & 12. & Advanced Training (0) & 3.20 & 1.05 \\
\hline 13. & $\begin{array}{l}\text { Vocational } \\
\text { Preparation (0) }\end{array}$ & 2.81 & .63 & 13.5 & Public Service (0) & 3.20 & .73 \\
\hline 14. & Public Service (0) & 2.75 & .65 & 13.5 & Humanism/Altruism $(0)$ & 3.20 & .80 \\
\hline 15. & $\begin{array}{l}\text { Social } \\
\text { Egalitarianism (O) }\end{array}$ & 2.43 & .68 & 15. & $\begin{array}{l}\text { Vocational } \\
\text { Preparation (0) }\end{array}$ & 3.17 & .70 \\
\hline 16. & Humanism/Altruism (O) & 2.42 & .76 & 16. & culture Awareness (0) & 3.07 & .67 \\
\hline 17. & Cultural Awareness (0) & 2.41 & .60 & 17. & $\begin{array}{l}\text { Social } \\
\text { Egalitarianism (0) }\end{array}$ & 2.82 & .81 \\
\hline 18. & $\begin{array}{l}\text { Social Criticism/ } \\
\text { Activism (0) }\end{array}$ & 2.39 & .64 & 18. & $\begin{array}{l}\text { Social Criticism } \\
\text { Activism (0) }\end{array}$ & 2.76 & .75 \\
\hline 19. & Of $f$-Campus Leaming (P) & 2.09 & .51 & 19. & Off-Campus Leaming (P) & 2.58 & .68 \\
\hline 20. & $\begin{array}{l}\text { Traditional } \\
\text { Religiousness (0) }\end{array}$ & 1.50 & .72 & 20. & $\begin{array}{l}\text { Traditional } \\
\text { Religiousness }\end{array}$ & 1.77 & .97 \\
\hline
\end{tabular}

- Letters in parentheses distinguish outome (O) from prooess (P) goals.

In Table 1, the major goa! areas are ranked by Is and Should Be means. The findings did not support the traditionally held view that outcome goals are most important; generally, respondents ranked process goals above outcome goals on both existing and preferred dimensions. Five of the seven process goals ranked in the top ten Is listing, and six in the top ten Should Be listing. 
All goals were rated on a one-to-five scale. Only three process goals - Community, Democratic Governance and Freedom - were perceived as having high importance (3.50 to 4.49) on the Is dimension. Five outcome goals and one process goal fell into the low importance range (1.50 to 2.49). The other eight outcome goals and three process goals on the Is dimension were perceived as having medium importance ( 2.50 to 3.49 ). Only on rating Advanced Training was the standard deviation (SD) above 1.0, indicating a low level of consensus among respondents. Greatest consensus was achieved on rating the importance of OffCampus Learning, Academic Development, Democratic Governance, and Meeting Local Needs.

The Should Be ratings were considerably higher than the Is ratings on all goals. Presidents and board chairmen perceived that universities should be doing more in the future than at present. In a time of fiscal restraint, the strong emphasis upon process goals may indeed enable a university to do more with less. Five process goals and four outcome goals were rated as having high importance (3.50 to 4.49); only one outcome goal, Traditional Religiousness, was regarded as having low importance. A fairly high level of consensus was achieved in rating all Should Be goals, except Advanced Training.

Maintaining a climate of Community on campus was perceived as the single most important goal area, both at present and in the future. Few would dispute the collegiality this goal suggests as a university ideal, but it was somewhat surprising that it rated so highly.

The relative importance of goals remained quite stable according to the Is and Should Be rankings. Three goals moved up by more than two rankings - Intellectual Orientation, Intellectual Environment, and Humanism/Altruism. Conversely, respondents felt that two goals should receive relatively less emphasis in the future than at present, Democratic Governance and Freedom, both process goals.

Presidents and board chairmen also rated ten miscellaneous and ten local Canadian goals (Table 2). The miscellaneous goals were included in the published IGI instrument, but the local Canadian goals were related to current issues drawn from an examination of Canadian university goal statements (McNeal, Konrad and Hodysh, 1981).

Three of the twenty single-item goal statements were perceived as having high importance ( 3.50 to 4.49 ), thirteen as medium importance (2.50 to 3.49 ), and four as low importance (1.50 to 2.49) on the Is dimension. The three that received a high importance rating were Institutional Reputation, Adult/Mature Student Programs, and Institutional Autonomy. All goal statements received higher ratings on the Should Be than on the Is dimension. In the respondents' perceptions, twelve of these goals should achieve high importance in the future, and only one - Intercollegiate Athletics - should have a low rating. Generally, the level of consensus on these goals was lower than on the major goal areas. Seven of the standard deviations exceeded 1.0 on the Is and six on the Should Be dimension.

As with major goal areas, respondents indicated shifts of more than two rankings on several Canadian and miscellaneous goal statements. Relatively less 
36 Abram G. Konrad and Joanne McNeal

Table 2

Perceptions of Miscellaneous and Canadian Goals

Ranked by Is and Should Be Means

\begin{tabular}{|c|c|c|c|c|c|c|c|}
\hline & Is & & & & Should Be & & \\
\hline Rank & Goal & Mean & SD & Rank & Goal & Mean & $\mathrm{SD}$ \\
\hline 1. & $\begin{array}{l}\text { Institutional } \\
\text { Reputation }(\mathrm{M}) \text { * }\end{array}$ & 3.87 & .89 & 1. & $\begin{array}{l}\text { Institutional } \\
\text { Reputation (M) }\end{array}$ & 4.40 & .69 \\
\hline 2. & $\begin{array}{l}\text { Adult/Mature Stud. } \\
\text { Prog. (C) }\end{array}$ & 3.72 & .88 & & $\begin{array}{l}\text { Organizational } \\
\text { Planning (M) }\end{array}$ & 4.28 & .74 \\
\hline 3. & $\begin{array}{l}\text { Institutional } \\
\text { Autonomy (M) }\end{array}$ & 3.50 & .89 & 3.5 & $\begin{array}{l}\text { Adult/Mature stud. } \\
\text { Programs (C) }\end{array}$ & 4.06 & .76 \\
\hline 4. & $\begin{array}{l}\text { Accessibility } \\
\text { Part-Time (C) }\end{array}$ & 3.46 & 1.15 & 3.5 & $\begin{array}{l}\text { Graduate } \\
\text { Literacy (M) }\end{array}$ & 4.06 & 1.05 \\
\hline 5. & $\begin{array}{l}\text { Accessibility: } \\
\text { Handicapped (C) }\end{array}$ & 3.34 & .85 & 5. & $\begin{array}{l}\text { Program Evaluation } \\
\text { (M) }\end{array}$ & 4.02 & .66 \\
\hline 6. & Graduate Iiteracy (M) & 3.33 & 1.17 & 6.5 & $\begin{array}{l}\text { Accessibility: } \\
\text { Handicapped (C) }\end{array}$ & 3.98 & .64 \\
\hline 7. & $\begin{array}{l}\text { Organizational } \\
\text { Planning ( } \mathbf{1})\end{array}$ & 3.20 & 1.04 & 6.5 & $\begin{array}{l}\text { Faculty Development } \\
\text { Evaluation (C) }\end{array}$ & & .71 \\
\hline 8. & $\begin{array}{l}\text { Faculty Development/ } \\
\text { Evaluation (C) }\end{array}$ & 3.06 & .83 & 8.5 & $\begin{array}{l}\text { Aocessibility: } \\
\text { Part-Time (C) }\end{array}$ & 3.87 & .99 \\
\hline 9. & Commmity Liaison (M) & 2.94 & .88 & 8.5 & Community Liaison (M) & 3.87 & .73 \\
\hline 10.5 & Progam Evaluation (M) & 2.93 & .97 & 10 & $\begin{array}{l}\text { Institutional } \\
\text { Autonomy (M) }\end{array}$ & 3.85 & .92 \\
\hline 10.5 & $\begin{array}{l}\text { Campus Consensus on } \\
\text { Goals (i1) }\end{array}$ & 2.93 & .97 & 11. & $\begin{array}{l}\text { New Faculty Enploy- } \\
\text { Patterns (C) }\end{array}$ & 3.69 & .82 \\
\hline 12. & $\begin{array}{l}\text { Extracurricular } \\
\text { Activities ( }(\mathrm{s})\end{array}$ & 2.91 & .91 & 12. & $\begin{array}{l}\text { Campus Consensus on } \\
\text { Goals (M) }\end{array}$ & 3.61 & .92 \\
\hline 13. & $\begin{array}{l}\text { Program Delivery/ } \\
\text { Remote Areas (C) }\end{array}$ & 2.80 & 1.23 & 13. & $\begin{array}{l}\text { Commanity Participation } \\
\text { in Planning (M) }\end{array}$ & 3.28 & .90 \\
\hline 14. & $\begin{array}{l}\text { French-Canadian } \\
\text { Cultural Programs (C) }\end{array}$ & 2.76 & 1.15 & 14. & $\begin{array}{l}\text { Extracurricular } \\
\text { Activities (M) }\end{array}$ & 3.24 & .95 \\
\hline 15. & $\begin{array}{l}\text { Commmity Participation } \\
\text { in Planning (M) }\end{array}$ & 2.67 & .95 & 15. & $\begin{array}{l}\text { French-Canadian } \\
\text { Cultural Programs (C) }\end{array}$ & 3.20 & 1.23 \\
\hline 16. & $\begin{array}{l}\text { New Faculty } \\
\text { Employment }\end{array}$ & 2.52 & .77 & 16. & $\begin{array}{l}\text { Development of Ed. } \\
\text { Technology (C) }\end{array}$ & 3.17 & 1.06 \\
\hline 17. & $\begin{array}{l}\text { Development of Ed. } \\
\text { Technology (C) }\end{array}$ & 2.43 & .92 & 17. & $\begin{array}{l}\text { Program Delivery/ } \\
\text { Remote Areas (C) }\end{array}$ & 2.94 & 1.30 \\
\hline & $\begin{array}{l}\text { Intercollegiate } \\
\text { Athletics (M) }\end{array}$ & 2.42 & 1.01 & 18. & $\begin{array}{l}\text { Bilingual Instruction } \\
\text { (C) }\end{array}$ & 2.48 & 1.42 \\
\hline 19. & $\begin{array}{l}\text { Bilingual Instruction } \\
\text { (C) }\end{array}$ & 2.04 & 1.12 & 19. & $\begin{array}{l}\text { Intercollegiate } \\
\text { Athletics (M) }\end{array}$ & 2.45 & .93 \\
\hline 20. & Experiential Learning (C) & 2.02 & .96 & 20. & Experiential Learning (C) & 2.44 & 1.06 \\
\hline
\end{tabular}

* Letters in parentheses distinguish miscellaneous (M) from Canadian (G) goals.

importance than at present should be given to Institutional Autonomy, Accessibility: Part-Time, and Program Delivery/Remote Areas; conversely, greater emphasis should be placed upon Organizational Planning, Program Evaluation, and New Faculty Employment Patterns.

In summary, there was a high level of consensus among respondents on the rating of university goals, particularly in the major goal areas. All Should Be 
Table 3

Means of University Coals that Reached Statistical Significanoe (.10) By Respondents' Position, and Region, Age, and Size of University

\begin{tabular}{|c|c|c|c|c|c|}
\hline Pasiti & ion & & President & & Board Chairman \\
\hline Vocational Preparation $(0)$ * & Is & & $2.93 h^{*}$ & & 2.521 \\
\hline Freedam (P) & Is & & $3.68 h$ & & 3.131 \\
\hline $\begin{array}{l}\text { Faculty Development/ } \\
\text { Evaluation (c) }\end{array}$ & $\mathrm{SB}$ & & 3.871 & & $4.25 h$ \\
\hline Region & & West & ontario & Quebec & Atlantic \\
\hline $\begin{array}{l}\text { Individual/Persanal } \\
\text { Development (O) } \\
\text { Humanism/Altruism (O) } \\
\text { Cultural Awareness (O) } \\
\text { Graduate Literacy (MD) } \\
\text { Extracurricular Activities (M) } \\
\text { Program Evaluation (M) } \\
\text { Program Delivery/Remote Areas ( } \\
\text { Aocessibility:Part-time (C) } \\
\text { Adult/Mature } \\
\text { Student Prograns (C) } \\
\text { Accessibility: Handicapped (C) }\end{array}$ & $\begin{array}{r}\mathrm{SB} \\
\mathrm{IS} \\
\mathrm{SB} \\
\mathrm{IS} \\
\mathrm{IS} \\
\mathrm{SB} \\
\text { (C) SB } \\
\mathrm{SB} \\
\mathrm{IS} \\
\mathrm{SB} \\
\mathrm{SB}\end{array}$ & $\begin{array}{l}3.38 \\
2.001 \\
2.93 \\
3.00 \\
2.501 \\
4.19 h \\
3.75 h \\
4.311 \\
4.25 h \\
4.44 h \\
4.33 h\end{array}$ & $\begin{array}{l}3.92 \\
2.75 h \\
3.40 h \\
3.67 \\
2.73 \\
4.13 h \\
2.731 \\
3.93 \\
3.80 \\
4.13 \\
3.671\end{array}$ & $\begin{array}{l}3.221 \\
2.19 \\
2.471 \\
2.501 \\
3.25 \\
4.25 h \\
2.251 \\
4.13 \\
3.251 \\
3.381 \\
4.00\end{array}$ & $\begin{array}{l}3.95 h \\
2.65 \\
3.20 h \\
3.80 h \\
3.33 h \\
3.601 \\
2.671 \\
3.201 \\
3.33 \\
3.93 \\
3.93\end{array}$ \\
\hline Age: & & $\begin{array}{c}\text { Before } \\
1900 \\
\end{array}$ & $1900-1929$ & $1930-59$ & $\begin{array}{l}\text { Since } \\
1960\end{array}$ \\
\hline $\begin{array}{l}\text { Innovation (P) } \\
\text { Acoontability/Efficiency (P) } \\
\text { Organizational Plarning (M) } \\
\text { ommmity Participation (M) } \\
\text { Adult/Mature } \\
\text { Student Programs (C) } \\
\text { Faculty Development } \\
\text { avaluation }\end{array}$ & $\begin{array}{l}\text { IS } \\
\text { SB } \\
\text { SB } \\
\text { SB } \\
\text { IS } \\
\text { SB }\end{array}$ & $\begin{array}{l}2.731 \\
3.531 \\
4.17 h \\
3.33 \\
3.58 \\
3.92 \\
4.17\end{array}$ & $\begin{array}{l}2.681 \\
3.511 \\
4.14 h \\
2.571 \\
3.43 \\
4.00 \\
3.71\end{array}$ & $\begin{array}{l}2.651 \\
3.83 \\
3.931 \\
3.60 h \\
3.401 \\
3.671 \\
3.60 i\end{array}$ & $\begin{array}{l}3.20 h \\
4.21 h \\
4.15 h \\
3.25 \\
4.15 h \\
4.45 h \\
4.25\end{array}$ \\
\hline Size: & & $\begin{array}{l}\text { Under } \\
4,000\end{array}$ & & $\begin{array}{l}4,000- \\
11,999\end{array}$ & $12,000+$ \\
\hline $\begin{array}{l}\text { Individual/Personal } \\
\text { Development (O) } \\
\text { Cultural Awareness (O) } \\
\text { Vocational Preparation (O) } \\
\text { Advanced Training (O) } \\
\text { Fesearch (O) } \\
\text { Innovation (P) } \\
\text { Extracurricular Activities (M) } \\
\text { French-Canadian Culture (C) }\end{array}$ & $\begin{array}{l}\text { IS } \\
\text { IS } \\
\text { IS } \\
\text { IS } \\
\text { SB } \\
\text { IS } \\
\text { SB } \\
\text { SB } \\
\text { SB } \\
\text { IS } \\
\text { SB }\end{array}$ & $\begin{array}{l}3.21 h \\
2.59 h \\
2.57 \\
2.221 \\
2.641 \\
2.851 \\
3.331 \\
3.58 h \\
3.46 h \\
2.691 \\
3.23\end{array}$ & & $\begin{array}{l}2.841 \\
2.35 \\
2.98 \\
3.21 \\
3.50 \\
3.44 \\
3.65 \\
3.151 \\
2.76 \\
2.291 \\
2.651\end{array}$ & $\begin{array}{l}2.611 \\
2.071 \\
3.11 h \\
3.80 h \\
4.07 h \\
3.82 h \\
4.20 h \\
3.43 \\
3.45 \\
3.64 h \\
4.00 h\end{array}$ \\
\hline
\end{tabular}

** fetters in parentheses identify outcome $(O)$, process (P), miscellaneous (M), and Canadian (C) goals.

* icwor case letters identify the high (h) means from the low (1) means in the statistical comparison on that iten.

ratings were higher than Is ratings, indicating that presidents and chairmen felt that universities should give higher priority to all goals than at present. A greater emphasis was placed upon process goals than on the traditional outcome goals of universities, although several interesting shifts in priority among goals were observed. 
A relatively stronger emphasis upon an Intellectual Orientation, Intellectual Environment and Humanism/Altruism, together with a lesser emphasis upon Accessibility: Part-Time and Program Delivery/Remote Areas may suggest a return to established traditions in higher education or simply a response to fiscal constraints. Coupled with an increased emphasis upon Organizational Planning, Program Evaluation and New Faculty Employment Patterns, the latter interpretation seems more plausible. The decreased importance given to democratic governance and freedom also suggests a response to constraints in institutional management. External pressures on universities may account for the major shifts in perceived importance of existing and preferred goals in Canadian universities.

\section{Goal Divergence}

Goal perceptions were examined to determine the degree of divergence that was related to the respondents' position, or the region, age and size of the university. Only the goal statements on which differences of means reached statistical signi. ficance at the .10 level are presented in Table 3 .

Respondent position. Generally, the goal perceptions of presidents and board chairmen were very similar. On only three of the forty goals were the differences statistically significant. Presidents rated Vocational Preparation and Freedom higher than did board chairmen on the Is dimension, while board chairmen rated Faculty Development/Evaluation higher on the Should Be dimension.

Geographical region. Do university goals differ across the major geographical regions of Canada?

Although eleven of the comparisons reached statistical significance, no clear distinctions could be made on regional bases in the perception of importance of outcome, process or miscellaneous goals. In rating local Canadian goals, respondents in the West differed from respondents in other parts of Canada on one Is and four Should Be statements. Respondents in the West were more concerned than others with increasing access to higher education - in remote areas, and for part-time, adult/mature, and handicapped persons.

University age. How do perceptions of university goals differ by the age of the university?

None of the observed differences in perceptions of outcome goals were statistically significant. The other seven comparisons that reached statistical significance did not provide a strong basis for differentiating among goals on the basis of institutional age. There was some evidence to suggest that institutions established since 1960 tend to be more concerned than older institutions with such goals as Innovation, Accountability/Efficiency, Adult/Mature Student Programs, and Faculty Development and Evaluation. Overall, however, goal perceptions did not vary much by institutional age.

University size. Finally, goal perceptions were examined by university size. Respondents' perceptions differed significantly on eleven comparisons, seven on outcome goals. 
The analysis lends support to the commonly held view that small institutions give more attention to the individual student than do large ones. Respondents at small institutions also rated Cultural awareness higher than they did at large institutions. Conversely, Vocational Preparation, Advanced Training, and Research were rated more highly in the large institutions than in the small ones. Among the single-item goal statements, Extracurricular Activities received a higher Should Be rating at small universities than at medium size universities; and French-Canadian Culture was rated highest on both dimensions at the large universities.

Goal divergence was not very great among respondents in this study. To be sure, a large response rate among board chairmen, and the participation of respondents from other constituency groups, may have resulted in different findings. Neither the position of the respondents nor the age of the university had much influence upon the perception of goal importance. Regional differences were found on a few local Canadian goals, and size differentiated somewhat on the perception of outcome goals. What was surprising was not that some differences were found, but that so few differences existed.

\section{CONCLUSIONS}

The purpose of this paper was to provide an overview of Canadian university goals as perceived by presidents and board chairmen. An intriguing profile of Canadian university goals has emerged.

1. The traditional outcome goals of a university were not rated highly in this study. Generally; process goals were perceived more highly than outcome goals on both existing and preferred dimensions.

2. When all goals were combined, the top-ranked goal was Institutional Reputation, followed closely by Community. Presidents and board chairmen appeared most concerned with how universities were perceived in society. Clearly, the public view of universities directly affects governmental policies on universities. The high emphasis upon community or collegiality within the university suggests a strong concern for institutional functioning.

3. When only outcome goals were considered, the order of emphasis was first upon teaching-related goals, then on research, and finally upon public service.

4. In the perception of university presidents and board chairmen, Canadian universities should place greater importance on all goal areas than at present. How this can be achieved in a time of fiscal constraints may be suggested in the increased emphasis proposed for such goals as Accountability/Efficiency, Organizational Planning, Program Evaluation, Faculty Evaluation, and New Faculty Employment Patterns. The greatest changes in university goals pro. posed by respondents were in areas related to university management.

5. There was a great deal of consensus among respondents regarding the importance of Canadian university goals. Only very few differences in goal percep- 
tions among respondents were related to their position, or to the region, age, and size of the university.

This overview of Canadian university goals provides a basis for developing a better understanding of Canadian universities. They resemble each other a lot, although a few differences attributed to region and size were observed. A list of goal priorities can serve as a basis for evaluation and planning, activities that can enhance the functioning of universities.

\section{REFERENCES}

Cohen, M.D., \& March, J.G. Leadership and Ambiguity. New York: McGraw Hill, 1974.

Conrad, C. University Goals: An Operative Approach. Journal of Higher Education, 1974, XLV 504-516.

Gross, E., \& Grambsch, P.V. University Goals and Academic Power. Washington, D.C.: American Council on Education, 1968.

Gross, E. \& Grambsch, P.V. Changes in University Organization. New York: McGraw Hill, 1974.

McNeal, J.C. Canadian University Goals: Perceptions of Presidents and Board Chairmen. Unpublished M.Ed. Thesis. Edmonton: The University of Alberta, 1982.

McNeal, J.C.; Konrad, A.G., \& Hodysh, H. University Purposes: Literature Review and Canadian Overview. Edmonton: The University of Alberta, 1981.

Parsons, T. et al. Theories of Society. New York: The Free Press, 1961.

Peterson, R.E. Goals for California Higher Education: A Survey of 116 College Communities. Princeton, N.J.: Educational Testing Service, 1973.

Peterson, R.E. The Crises of Purpose. Definition and Uses of Institutional Goals. Princeton, N.J.: Educational Testing Service, 1970.

Peterson, R.E. \& Uhl, N.P. Formulating College and University Goals: A Guide for Using the IGI. Princeton, N.J.: Educational Testing Service, 1977.

Piccinin, S., \& Joly, J.M. The Goals of the University of Ottawa, What They Are and What They Should Be, Volumes I and II. Ottawa: University of Ottawa, 1978.

University of Manitoba. Attitudes Towards Goals of the University of Manitoba. Winnipeg: The University of Manitoba, 1977. 